\title{
締固め完了エネルギーに基づくコンクリートの 締固め完了範囲の評価方法に関する研究
}

\author{
梁 俊1・丸屋 剛2・坂本 淳1・松元＼cjkstart淳一1・下村＼cjkstart泰造3・滝沢＼cjkstart正徳3 \\ 1正会員 大成建設（株）技術センター土木技術研究所（†245-0051 神奈川県横浜市戸塚区名瀬町344-1） \\ E-mail: rn-zn-00@pub.taisei.co.jp \\ 2フェロー会員 大成建設（株）技術センター土木技術研究所（同上） \\ 3正会員 大成建設（株）千葉支店外環自動車道田尻作業所 \\ ( テ272-0014 千葉県市川市田尻2丁目4番20号)
}

\begin{abstract}
本研究では, コンクリートのスランプをパラメータとして, 実構造物の配筋をモデル化した要素試験体 を用いて，コンクリートの締固め完了エネルギーから施工に使用したコンクリートが必要とする内部振動 機の挿入間隔と振動時間を定量的に評価する方法を検討し，累積された内部振動機による振動エネルギー が，コンクリートの締固めを完了するのに必要なエネルギー以上となった範囲を締固め完了範囲とするこ とで，鉄筋コンクリートの締固め完了範囲を評価することが可能であることを実寸大試験体より検証した. また，仕上げの締固めを行う後追い締固めにおいては，コンクリートのモルタル分が流されないため，締 固め時間を適当に長くしても品質上は問題がないことを検証した.
\end{abstract}

Key Words : concrete, compactability, compaction completion energy, compaction degree

\section{1. はじめに}

土木学会コンクリート標準示方書（以下，示方書[施 工編]）などのコンクリートの締固めに関する基準では, 内部振動機を使用する場合の締固め時間や挿入間隔，締 固め終了の目安が記述されている1), 2). しかしながら, それらは，いずれもコンクリート締固めの振動時間，締 固めの有効範囲，打込み方法についての定性的表現に留 まっており，理論的根拠に乏しく，施工現場においては 経験的判断に委ねられているところが多い。したがって 施工計画の段階で，コンクリートの定量的な打設計画を 策定することが難しくなり，施工計画と施工の実状の承 離により，施工欠陥を引き起こす場合がある3).

内部振動機の締固め効果に関する研究はこれまでに数 多く行われており，振動機の周波数，振動時間，コンク リートの性質など，さまざまな要因と締固め特性との関 係が研究されている4) . 土木学会や日本コンクリート 工学会のコンクリートの施工に関連する委員会では，コ ンクリートのフレッシュ性状の試験に関していろいろな 面で検討を行った ${ }^{8)-10)}$.

著者らは，締固め度を締固めの進行程度の指標として， スランプ $5 \mathrm{~cm} \sim 15 \mathrm{~cm}$ 程度のコンクリートを対象として, コンクリートが締め固められるのに必要なエネルギーす
なわち，締固め完了エネルギーを定量的に評価できる室 内試験方法を提案している

ここに，締固め完了エネルギーは，型枠中のコンクリ 一トが見掛けのかさ密度から，コンクリートの配合の理 論密度に至るまでに必要なエネルギーを言う。したがっ て, 本研究では，コンクリートが理論密度まで締め固め られた状態をコンクリートが充分締め固められた状態と した.

本研究では，コンクリートのスランプをパラメータと し，実構造物をモデル化した模擬試験体を用いて，コン クリートの締固め完了エネルギーから施工に使用したコ ンクリートが必要とする内部振動機の挿入間隔と振動時 間を定量的に評価する方法を検討し，実寸大試験体でそ の結果を検証した。

\section{2. 締固め完了範囲の評価方法}

\section{(1) 締固め完了エネルギ一の測定方法}

コンクリートの締固めとは，コンクリートを，締固め 前における型枠中のコンクリートが見掛けのかさ密度か ら，コンクリートの配合の理論密度に至るまで変形させ ることであると考えることができる. そこで，締固めの 
程度は，円筒容器中の試料の最も高い部分を高さとする 円筒体積に対するコンクリート試料の真の体積の比とし て捉え，これを締固め度 $\gamma$ と定義する. 締固め度 $\gamma$ は式(1) により表すことができる11).

$$
\gamma=\frac{m / \rho_{0}}{A h} \times 100=\frac{H_{0}}{h} \times 100
$$

ここに, $\gamma$ : 締固め度(\%), $H_{0}$ : 配合に基づく理論上の 単位容積質量まで締め固められた時の試料の高さ $(\mathrm{mm})$, $h:$ 任意の締固め時間における試料の高さ $(\mathrm{mm}), \mathrm{m}:$ 試 料の質量 $(\mathrm{kg}), \rho_{0}$ : 試料の単位容積質量 $(\mathrm{kg} / \mathrm{l}), A$ : 円筒 容器の底面積 $\left(\mathrm{mm}^{2}\right)$

締固めエネルギーは式(2) ${ }^{12)} に よ り$ 求めることができる. 一方，変形進行曲線を図-2の模式図に示す.

$$
E_{t}=\frac{\rho_{0} \alpha_{\max }^{2}}{4 \pi^{2} f} t
$$

ここに, $E_{t}: t$ 秒間にコンクリートが受ける締固めエ ネルギー $(\mathrm{J} / l), t$ : 振動時間( $(\mathrm{s}), \quad \alpha_{\max }$ : 最大加速度（sin 曲線の平均振幅の半分) $\left(\mathrm{m} / \mathrm{s}^{2}\right), f$ : 振動数 $\left(\mathrm{s}^{-1}\right), \rho_{0}$ : 単位 容積質量 $(\mathrm{kg} / \mathrm{l})$

コンクリートの締固め完了エネルギーを測定する試験 装置を図-1に示す。直径が240mmの試験容器の中でスラ ンプ試験を行い，振動台にセットして振動をかける。 そ の際に試料の上面の沈下量と振動台の加速度, 振動数を 記録する．記録された上面の沈下量を用いて，式(1)に より締固め度を求める. また, 加速度, 振動数を用いて 式(2)により, 締固めエネルギーを求め, 締固めエネル ギーと締固め度の関係から, 締固め完了エネルギーを算 定する.

締固めエネルギーの計算式には，重力の影響が入って ない ${ }^{13)}$.コンクリートの締固めに与えられる重力の影響 は場所によって変わらないのが原因であると考える．重 力を考慮しない場合，上下に振動を与えても，横に振動 を与えても，コンクリート試料が受けているエネルギー には大きな差がないと考えられる.また，ここでのコン クリートの締固め完了エネルギーは，コンクリート試料 が容器の中で締め固められるのに必要なエネルギーで, コンクリートを流動させるために消費したエネルギーは 含まれてない.

\section{（2）締固め完了範囲の判断}

コンクリートを締め固めるにはエネルギーが必要であ り，一般には内部振動機をコンクリート中で振動させる ことにより，そのエネルギーは与えられる．振動機によ る振動をコンクリートに与え続けると，そのエネルギー

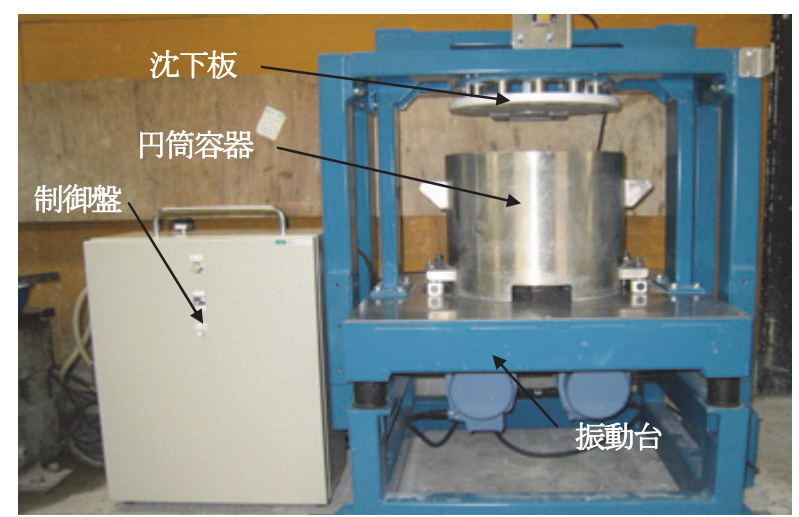

図-1＼cjkstart締固め試験装置

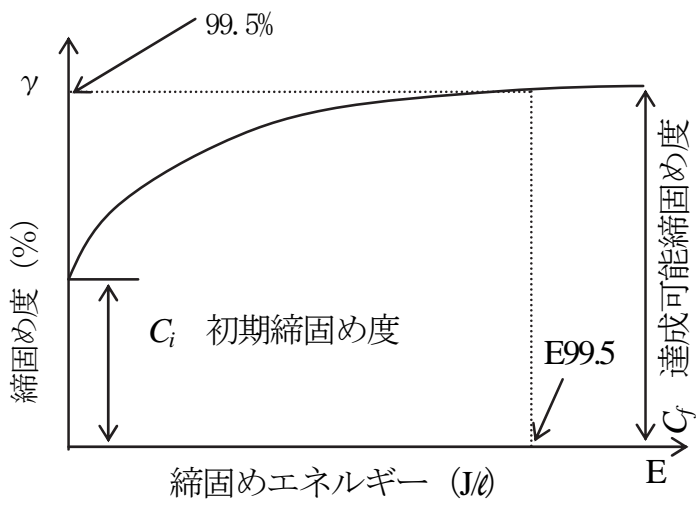

図-2 変形進行曲線の模式図

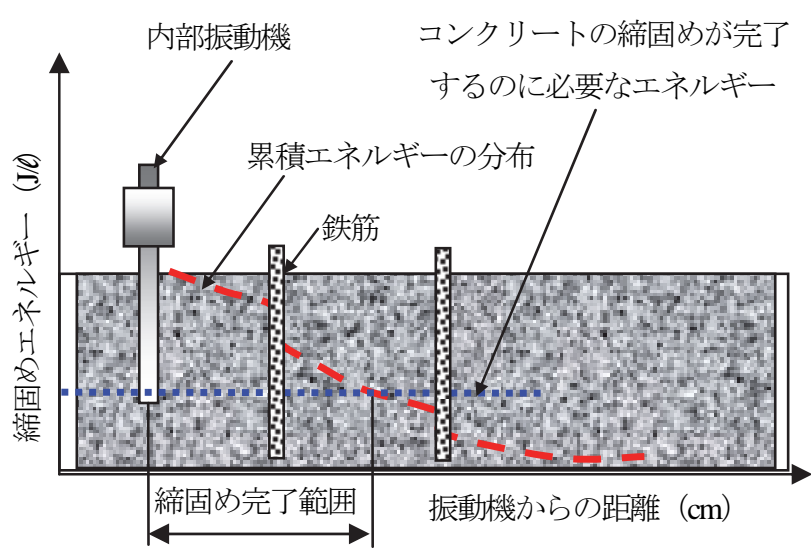

図-3＼cjkstart締固めエネルギー分布の概念図

は累積されるが，振動機から距離が遠い程，累積される エネルギーは小さくなるので, 振動機からの距離による エネルギーの分布は図-3の赤い破線のように示すことが できる．累積されたエネルギーが，コンクリートの締固 めを完了するのに必要なエネルギー以上となる範囲を締 固め完了範囲（赤破線が青点線より大きい範囲）とする. なお，過密配筋によりコンクリートが鉄筋間を通過でき なく, 空隙が発生した場合, その空隙により振動加速度 の伝播は阻止され，エネルギーの累積はできなくなる. 
既往の研究によると7, 伝播中の振動波の振動数はほ とんど変化しないので，振動時間を一定にした場合， エネルギーは加速度 $\alpha_{\max }$ の関数である。 したがって，式 (2)によりコンクリートに累積されるエネルギーの分布 を求めることができる ${ }^{14)}$.

著者らは，無筋コンクリートを対象とした一連の実 験の結果，締固め完了エネルギーによる内部振動機の 締固め範囲の評価手法を確立した ${ }^{14)}$. 本研究では，無筋 コンクリートを対象とした一連の評価手法および結果 を鉄筋コンクリートの評価に拡張し，実大試験で上記 評価手法の妥当性の最終確認を行った.

\section{3. 鉄筋を埋設した模擬試験体における加速度分 布の測定実験}

\section{(1) 模擬試験体および加速度測定方法}

6章で詳述する実構造物の高密度配筋部材と同等の配 筋条件にした図-4に示寸模擬試験体を用いて ${ }^{15}$ ，内部振 動機からの距離に応じた加速度の分布を，スランプを パラメータとした3配合について測定した．模擬試験体 が模擬した部位を図-5に示す。図-6に鉄筋の配置および 加速度センサの設置状況を示す．実構造物と同じ配筋 条件となるように，型枠内には，主鉄筋D41@128の二 段配筋，配力鉄筋D25@150の鉄筋に加えて，D25のせん 断補強鉄筋，D25の配力鉄筋，せん断補強鉄筋である D25のプレート定着型せん断補強鉄筋を設置した。 かぶ りの厚さは側面が $130 \mathrm{~mm}$ ，底面が $89 \mathrm{~mm}$ である．加速度

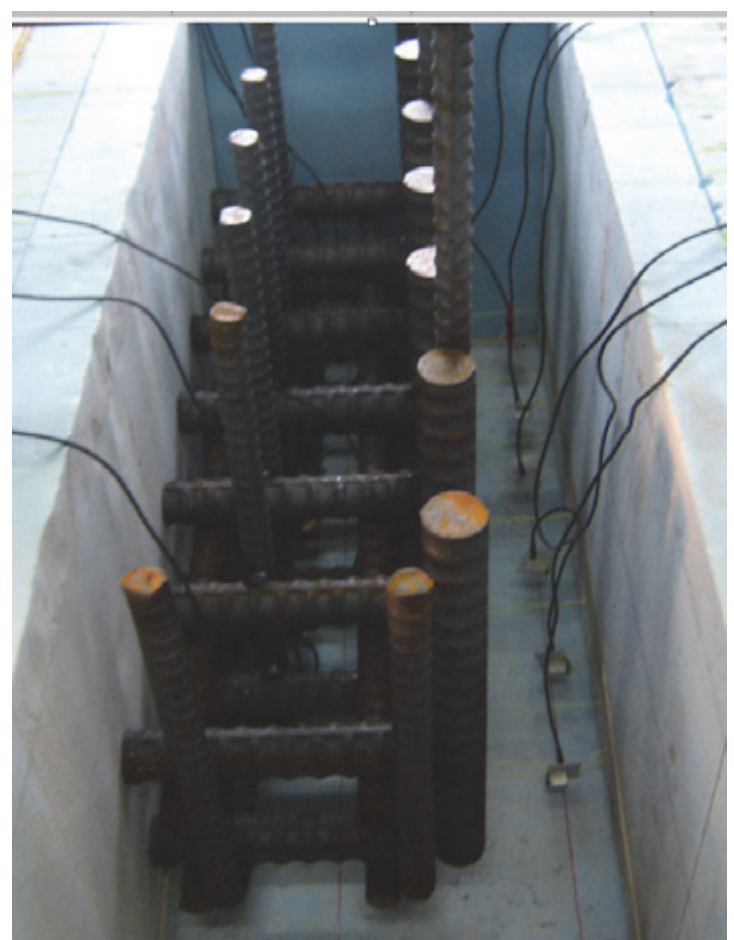

図-4＼cjkstart模擬試験体の配筋と加速度センサの配置状況

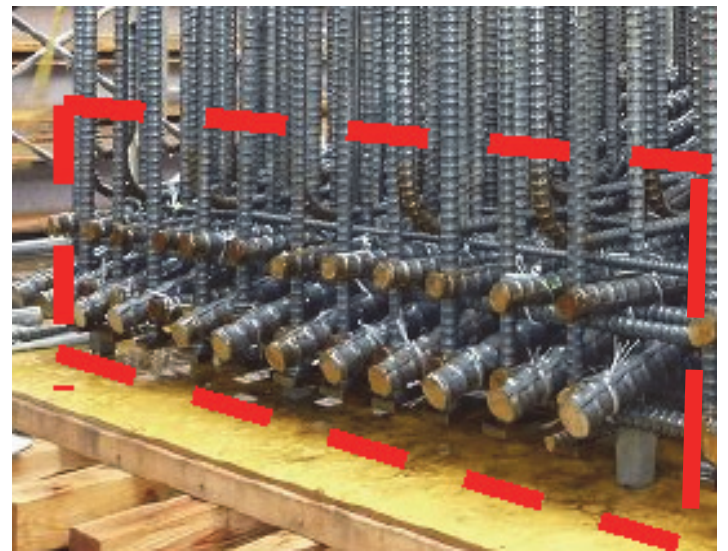

図-5＼cjkstart模擬試験体が模擬した部位（赤枠部）



B-B平面図
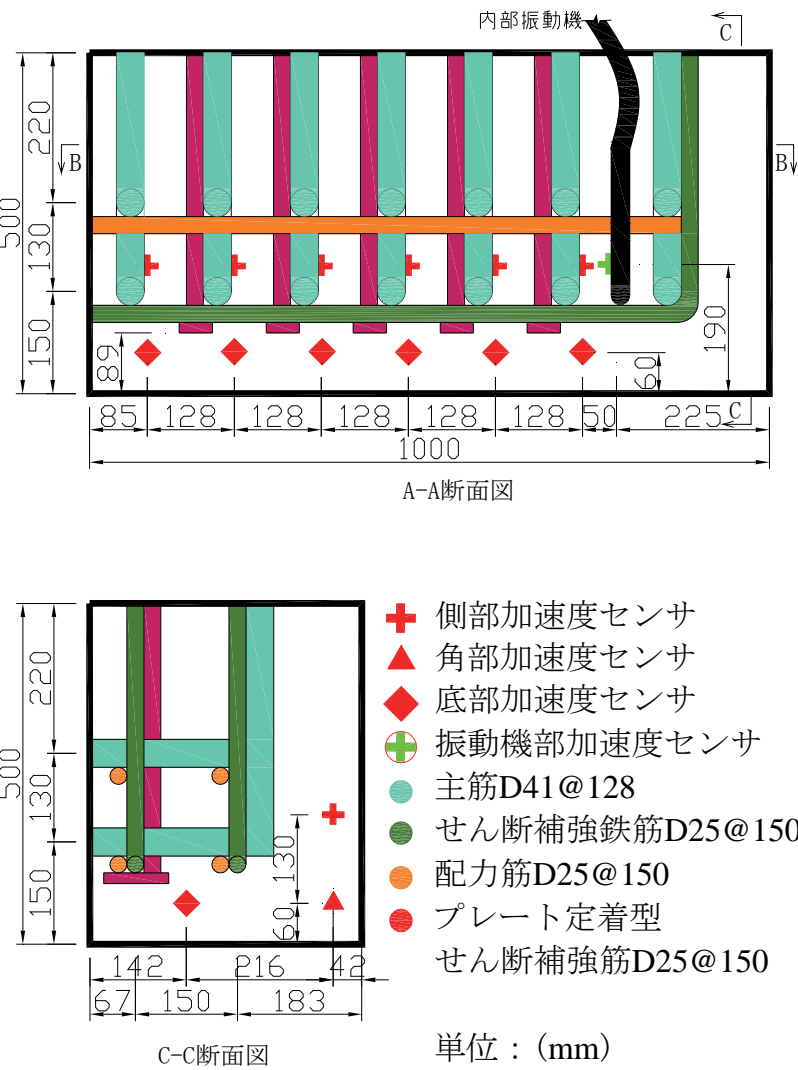

図-6 模擬試験体の概要，鉄筋および加速度センサの配置 
センサの取付け位置として，図-6に示すように，加速度 の減衰が著しいと思われる底面のかぶり部，側面かぶり 部および側面と底面の角部に設置した，加速度センサは 長手方向に128mm間隔で配置した．加速度センサは寸法 がL14.0 $\times$ W14.0 $\times$ H17.4mmで，内部振動機からの距離の 短長に応じて計測可能域が50G，20G，および10Gの3種 類のものを使用した． $\phi 60 \mathrm{~mm}$ の内部振動機の先端を型 枠の底面から $90 \mathrm{~mm} の$ 位置まで挿入して締固めを 15 秒間 行った.

締固め時間の設定においては，コンクリート標準示方 書に記述されている締固め時間の最大值である15秒1に 設定した. 内部振動機の先端から100mmの位置に測定可 能域200Gの加速度センサを取り付けて, 振動機表面の 加速度も測定した.

\section{（2）使用材料およびコンクリートの配合}

水セメント比を $50 \%$ で一定とし, 細骨材率を $45 \%$ 程度 として単位水量を変化させてスランプ8，12，15cmの配 合を選定した。 なお，コンクリートの状態を最適にする ため, 細骨材率は微調整を行った。コンクリートの配合 を表-1に示す．使用材料を表-2に示す．なお，第6章に 記述する実大規模施工実験においても同じ材料と配合を 使用した.

\section{（3）締固め完了エネルギーによる模擬試験体の締固め 完了範囲の評価結果}

図-1に示寸締固め試験装置を用いて，各配合のコンク リートの締固め完了エネルギーを測定した．コンクリー トのフレッシュ性状と単位容積質量，およびコンクリー トの締固め完了エネルギーを表-3に示す，本実験に使用 したコンクリートは, 締固め完了エネルギーがスランプ の増加により小さくなっていることがわかる ${ }^{16}$.

配筇およひ型枠の形状の影響により, 試験体内部の各 部位に伝わってくる加速度は相違する. 特に伝わってき た加速度の減衰が大きいかぶり部では，側面，底面，角 部に着目し，測定された加速度と振動時間から振動時間 内で累積された締固めエネルギーを計算することで内部 振動機からの距離と締固めエネルギーの関係を評価した。 以下に，底面における締固め完了範囲の評価を一例とし て，コンクリートの配合に固有な締固め完了エネルギー と振動機からの距離による締固めエネルギーの分布から 締固め完了範囲を求める方法を説明する.

内部振動機は振動機内部の偏鍾の回転により振動する ため，鉛直線を中心に回転しながら振動する．したがっ て, 一定の方向に対しての加速度の変化は, 近似的に sin曲線で示すことができる. しかしながら，フレッシ ユコンクリートの材質の不均一さ，加速度センサと粗骨 材の衝突などにより，実測したsin曲線の振幅は図-7に示
すように一定ではなく乱れがある.

本研究では, 示方書[施工編]に示されている締固め時 間の最大值が15秒であることから，15秒間のsin曲線の振

表-1 コンクリートの配合

\begin{tabular}{|c|c|c|c|c|c|c|c|c|}
\hline \multirow{3}{*}{ 区分 } & \multirow{3}{*}{$\begin{array}{l}\text { W/C } \\
(\%)\end{array}$} & \multirow{3}{*}{$\begin{array}{c}\text { S/a } \\
(\%)\end{array}$} & \multicolumn{5}{|c|}{ 単 位 量 $\left(\mathrm{kg} / \mathrm{m}^{3}\right)$} & \multirow{3}{*}{$\left(\begin{array}{c}\mathrm{AE} \text { 減水 } \\
\text { 剤 } \\
(\mathrm{C} \times \%)\end{array}\right.$} \\
\hline & & & \multirow{2}{*}{\begin{tabular}{|l|} 
水 \\
$\mathrm{W}$
\end{tabular}} & \multirow{2}{*}{$\begin{array}{l}\text { セメ } \\
\text { ント } \\
\text { C }\end{array}$} & \multicolumn{2}{|c|}{$\begin{array}{c}\text { 細骨材 } \\
\mathrm{S} \\
\end{array}$} & \multirow[t]{2}{*}{$\begin{array}{c}\text { 粗骨材 } \\
\text { G }\end{array}$} & \\
\hline & & & & & S1 & $\mathrm{S} 2$ & & \\
\hline スランプ 8cm & 50 & 44.9 & 150 & 300 & 490 & 338 & 1050 & 0.85 \\
\hline スランプ $12 \mathrm{~cm}$ & 50 & 45.3 & 156 & 312 & 488 & 335 & 1029 & 0.50 \\
\hline スランプ $15 \mathrm{~cm}$ & 50 & 45.5 & 162 & 324 & 482 & 333 & 1010 & 0.85 \\
\hline
\end{tabular}

表-2 使用材料

\begin{tabular}{|c|c|c|}
\hline \multicolumn{2}{|c|}{ 種類 } & 品質 \\
\hline \multicolumn{2}{|c|}{ セメント(C) } & 高炉セメント B 種 : 密度 3.04g/cm ${ }^{3}$ \\
\hline \multirow{2}{*}{ 細骨材 } & $\mathrm{S}_{1}$ & $\begin{array}{l}\text { 千葉県君津産山砂 : 表乾密度 } 2.58 \mathrm{~g} / \mathrm{cm}^{3} \text {, } \\
\text { 吸水率 } 1.58 \%\end{array}$ \\
\hline & $\mathrm{S}_{2}$ & $\begin{array}{l}\text { 高知県鳥形山産石灰砕砂 : 表乾密度 } \\
2.66 \mathrm{~g} / \mathrm{cm}^{3}, \text { 吸水率 } 1.06 \%\end{array}$ \\
\hline \multicolumn{2}{|c|}{ 粗骨材(G) } & $\begin{array}{l}\text { 高知県鳥形山産石灰砕石：表乾密度 } \\
2.70 \mathrm{~g} / \mathrm{cm}^{3} \text { ，吸水率 } 0.60 \% ， \text { 最大寸法 } 20 \mathrm{~mm}\end{array}$ \\
\hline \multicolumn{2}{|c|}{ 混和剤 $\left(\mathrm{A}_{d}\right)$} & リグニンスルホン酸系 $\mathrm{AE}$ 減水剤（標準型） \\
\hline
\end{tabular}

表-3 フレッシュ性状と締固め完了エネルギー

\begin{tabular}{|c|c|c|c|c|c|}
\hline 区分 & $\begin{array}{c}\text { スラン } \\
\text { プ } \\
(\mathrm{cm})\end{array}$ & $\begin{array}{c}\text { 空気 } \\
\text { 量 } \\
(\%)\end{array}$ & $\begin{array}{c}\text { ニンクリ温度 } \\
(\mathrm{C})\end{array}$ & $\begin{array}{c}\text { 単位容質量 } \\
\left(\mathrm{t} / \mathrm{m}^{3}\right)\end{array}$ & $\begin{array}{c}\text { 締固め完 } \\
\text { 了エネル } \\
\text { ギー }(\mathrm{J} / \mathrm{l})\end{array}$ \\
\hline スランプ 8cm & 9.0 & 5.1 & 20 & 2.317 & 1.78 \\
\hline スランプ $12 \mathrm{~cm}$ & 12.0 & 4.8 & 19 & 2.321 & 1.03 \\
\hline スランプ 15cm & 15.0 & 4.5 & 20 & 2.324 & 0.78 \\
\hline
\end{tabular}

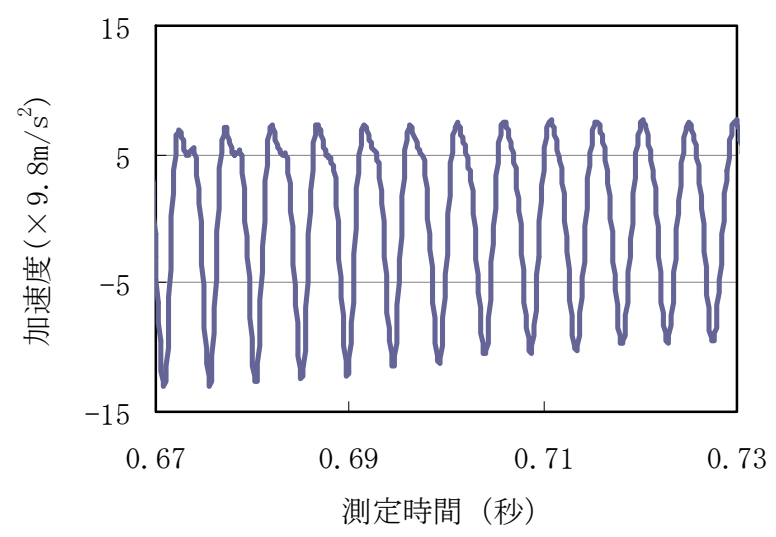

図-7 加速度波形の一例 


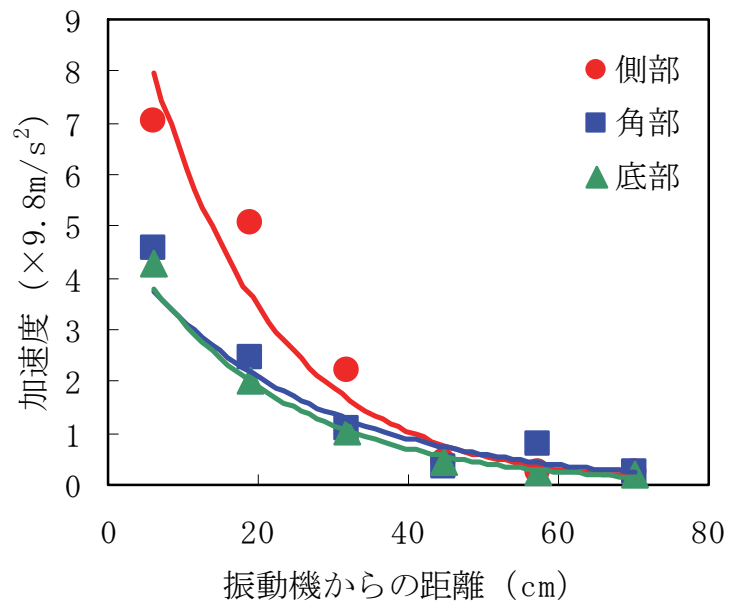

図-8＼cjkstart各部位の加速度の伝播(スランプ 8cm)

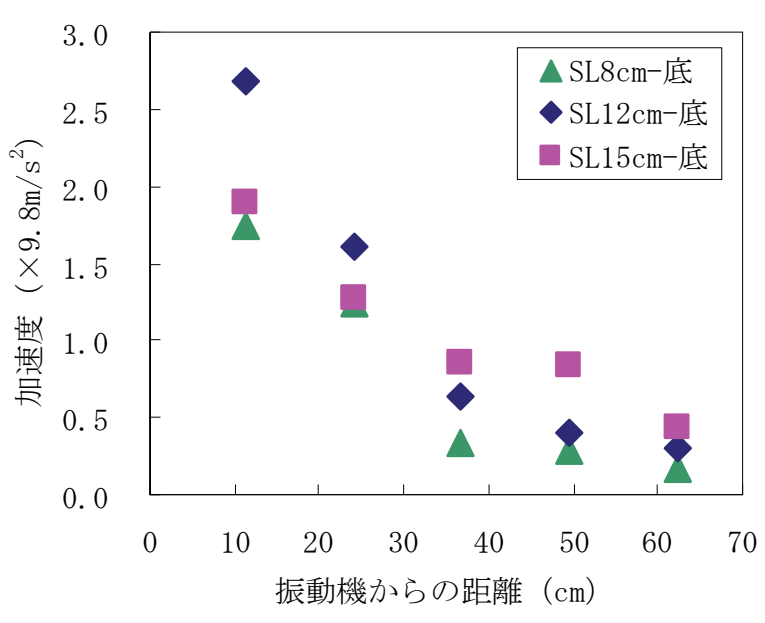

図-9 最大加速度の分布(底部)

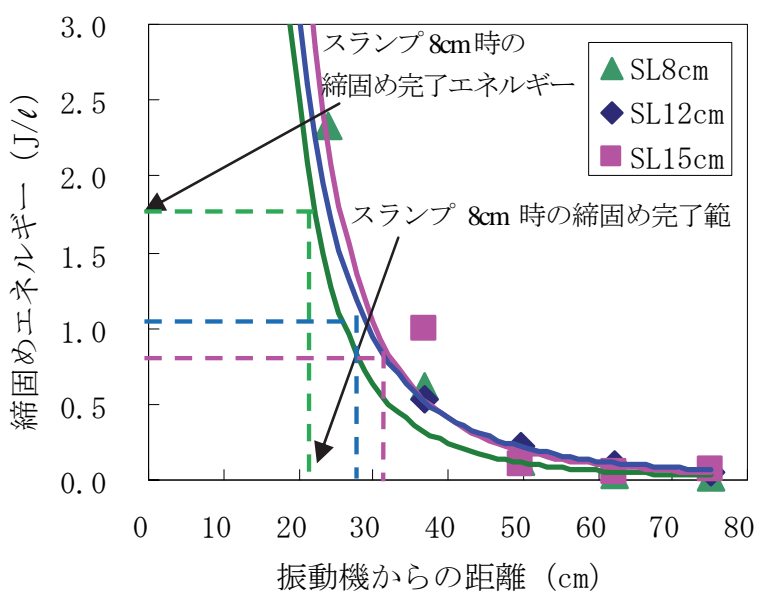

図-10 配合別締固めエネルギーの分布(底部)

幅を平均化した $\sin$ 曲線の平均振幅の半分を各加速度計 が測定した最大加速度とした。

スランプ $8 \mathrm{~cm}$ の配合を使用した場合の各部位の加速度 の伝播状況を図-8に示す．図が示すように，側部の加速 度の伝播が角部と底部よりよく, 角部が底部より若干よ い. 本実験において, 締固め完了範囲は底部の加速度伝
表-4 締固め完了範囲の計算值および実測値 (振動機からの距離)

\begin{tabular}{|c|c|c|c|c|}
\hline \multicolumn{2}{|r|}{ 配合 } & $\begin{array}{c}\text { スランプ } \\
8.0 \mathrm{~cm} の \\
\text { 配合 }\end{array}$ & $\begin{array}{c}\text { スランプ } \\
12.0 \mathrm{~cm} の \\
\text { 配合 }\end{array}$ & $\begin{array}{c}\text { スランプ } \\
15.0 \mathrm{~cm} の \\
\text { 配合 }\end{array}$ \\
\hline \multirow{3}{*}{$\begin{array}{l}\text { 計 } \\
\text { 算 } \\
\text { 值 }\end{array}$} & $\begin{array}{c}\text { 計算值（底） } \\
(\mathrm{cm})\end{array}$ & 22.2 & 29.3 & 33.1 \\
\hline & $\begin{array}{c}\text { 計算值（角） } \\
(\mathrm{cm})\end{array}$ & 24.2 & 32.3 & 39.0 \\
\hline & $\begin{array}{c}\text { 計算值（側） } \\
(\mathrm{cm})\end{array}$ & 26.5 & 34.7 & 36.3 \\
\hline \multirow{3}{*}{$\begin{array}{l}\text { 測 } \\
\text { 定 } \\
\text { 值 }\end{array}$} & $\begin{array}{c}\text { 側面充填状態 } \\
(\mathrm{cm})\end{array}$ & 45.0 & 50.0 & 75.0 \\
\hline & $\begin{array}{c}\text { 上面盛上り状態 } \\
\text { (cm) }\end{array}$ & 21.0 & 30.0 & 37.5 \\
\hline & $\begin{array}{c}\text { カット面充填状態 } \\
(\mathrm{cm})\end{array}$ & $12.8 \sim 25.6$ & $25.6 \sim 38.4$ & $25.6 \sim 38.4$ \\
\hline
\end{tabular}

播により決められることがわかる．スランプ12，15cm の配合を使用しても同じ傾向であった.

底部にセットした各加速度センサが測定した加速度か ら計算した内部振動機の中心からの距離に忍じた最大加 速度の分布を図-9に示寸．加速度の分布はコンクリート のスランプの大小に応じて変化しているとは必ずしも言 えない

そこで，式(2)により，各配合のコンクリートを用い た場合の加速度センサがセットされている各点における 15秒間の累積締固めエネルギーを求めた．図-10に底部 におけるエネルギーの分布を示した．図-10の緑の破線 が示すように, 締固め完了エネルギー相当の累積エネル ギーを受けた位置までをスランプ $8 \mathrm{~cm}$ 配合のコンクリ 一トを使用した場合の締固め完了範囲とした。また，ス ランプ $12 \mathrm{~cm}$ の配合の場合の締固め完了範囲は，青の破 線により，スランプ $15 \mathrm{~cm}$ 配合の場合は，ピンクの破 線により求めた。同様の手法により, 型枠の側部および 角部について各配合の締固め完了範囲を評価した結果を 表-4の計算值欄に示す，各配合において，締固め完了範 囲が最小である底部の締固め完了範囲をその配合の最小 締固め完了範囲とした．締固め完了範囲の計算值と比較 検討寸るため, 硬化後の試験体の締固め完了範囲を測定 し，表-4の測定值欄に示す．測定值の詳細な測定方法は 次の章に述べる.

\section{4. 硬化後試験体の観察による締固め完了範囲の 評価}

前章で述べたように，測定された最大加速度により求 
めた内部振動機からの距離に応じた締固めエネルギーの 分布と使用したコンクリートの締固め完了エネルギーか ら，任意のスランプのコンクリートと一定の振動時間に おける内部振動機の締固め完了範囲を計算することがで きる．この計算方法で計算した締固め完了範囲と実際の 締固め完了範囲を比較するため，加速度センサを設置せ ずに図-4と同様な型枠・配筋・締固め条件で試験体を作 製し，硬化後の試験体の締固め状態をコンクリート表面 を観察することにより確認した.

現実の打込みに近い状態でコンクリートを型枠内に投 入するため， $\phi 100 \mathrm{~mm}$ のポンプ配管先端を想定し，図-11 の写真(1)に示すように，先端をカットして開口部を $\phi 100 \mathrm{~mm}$ としたロードコーンを使用した. カットしたコ ーン端面( $\phi 100$ 側)は型枠底面から500 mm程度の高さにセ ットしてコンクリートを打ち込んだ。140lのコンクリー トをバケツにより11回に分けて(約13//回)ロードコーンを 通じて型枠内に投入した。一例として，スランプ8cmの コンクリートを使用した場合の試験体の打込多状況を図 -11の写真(1)に示す.

本研究では，投入したコンクリートが締め固められて 配合から理論的に計算した密度に達した状態を締固め完 了と定義している．したがって，140lのコンクリートを $\mathrm{L} 1000 \times \mathrm{W} 400 \times \mathrm{H} 350$ の型枠に投入した場合，完全に締固
めができて配合から理論的に計算した密度に達したとす れば，鉄筋の体積を考慮してもその高さは36.5cmになる ベきである. 一例として，スランプ8cmのコンクリート を使用した場合の試験体を図-11の写真(4)に示す.

試験体に対して，側面充填状況，カット面状況，およ び上面の試料盛上り状況から締固め完了範囲を以下，考 察する. 図-11の写真(2)が投入後の状況，写真(3)が締固 め後の上面状況, 写真(4)が脱型後側面の状況である. 側面の充填状態から見ると振動機の挿入位置から水平距 離で45cmのところまで充填されたように見える.

また，硬化後試験体のカット面の状況を図-12に示す. 写真(1)にカットした面を示す. 試験体は，まず，プレ 一ト定着型せん断補強筋に沿って縦断方向にカットした. カットされた部分を振動機からの距離12.8，25.6，38.4, 51.2cmの位置（図-12写真(1)のA，B，C，Dの位置）で横 断方向に切断して試験体かぶり部の充填状況を確認した. 切断した部分の断面を写真(2)に示す. 振動機から距離 12.8cmまでの断面には，不充填部が見られなかったが， 写真(2)に示すように，振動機からの距離25.6cm以降の断 面には，明らかな不充填部が見られた。 これは，締固め 十分と締固め不十分の境が12.8〜25.6cmの間である可能 性が大きいことを示す。 また，側面の充填状態から判断 した締固め完了範囲45cmよりははるかに狭い範囲であ

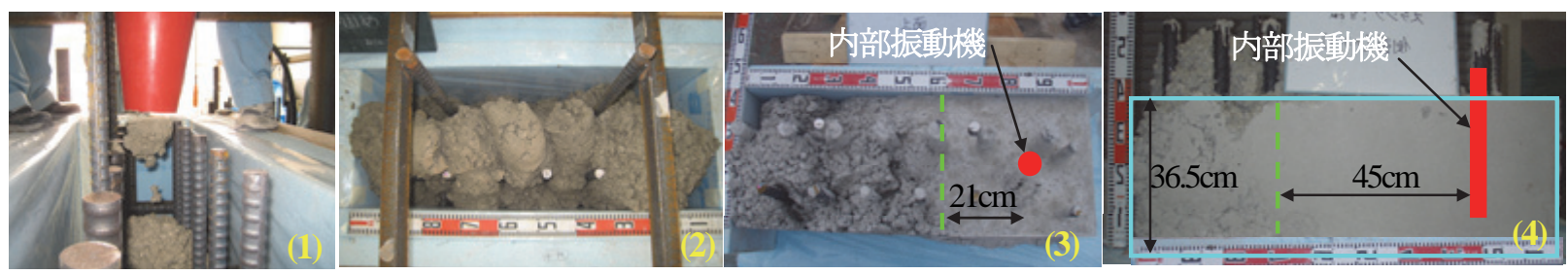

図-11 コンクリートの投入状況および硬化後の側面状況(スランプ8cm)

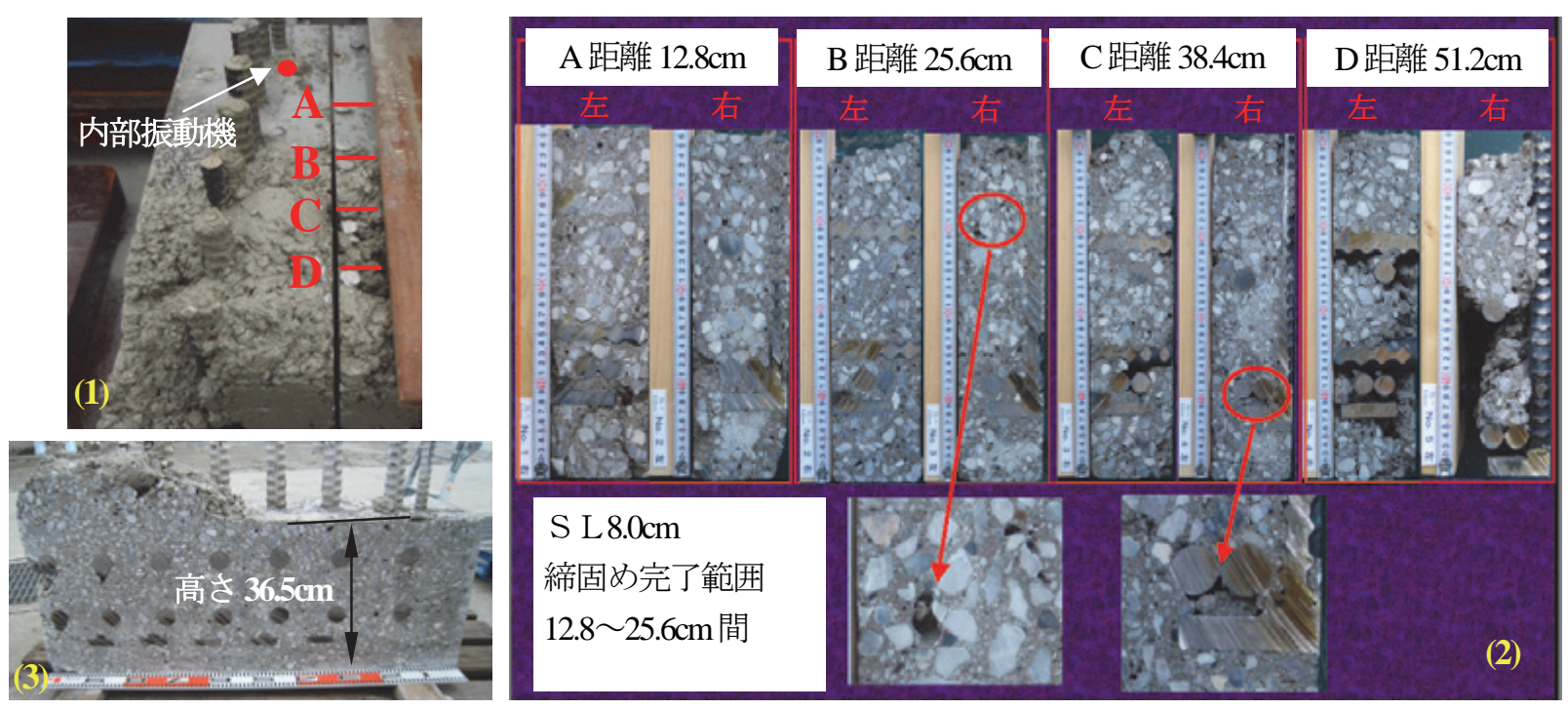

図-12 硬化後の試験体カット後の状況(スランプ8cm) 


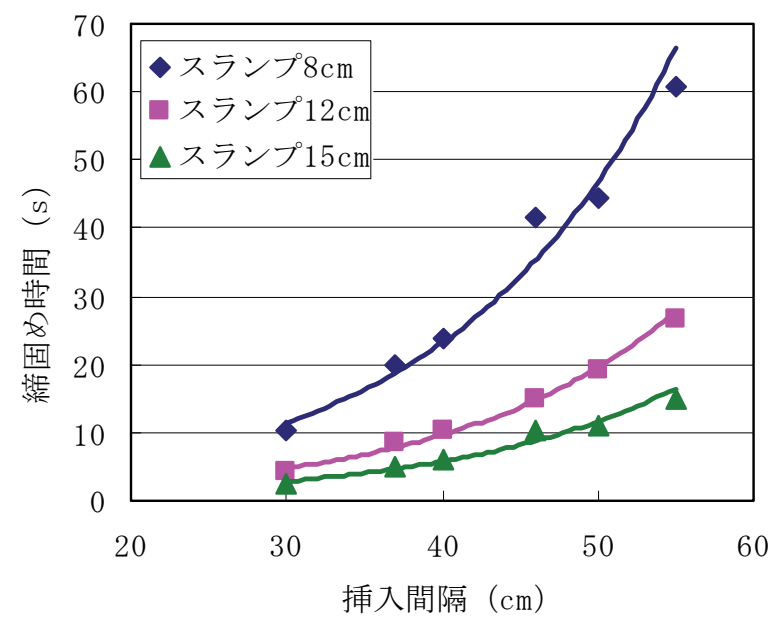

図-13 内部振動機の挿入間隔と締固め時間の関係

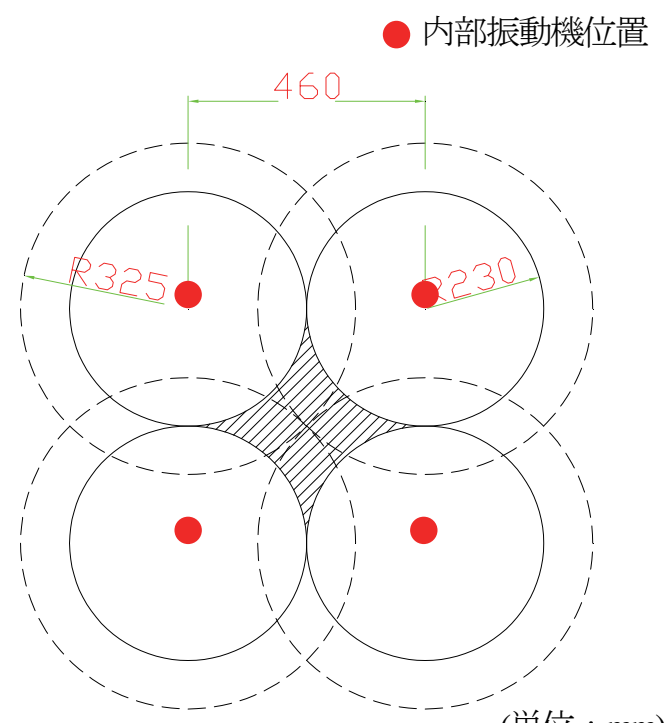

(単位 : mm)

図-14 内部振動機の締固め範囲と挿入間隔の関係

ることから，側面の充填状態の目視による判断だけで, 締固めの程度を判断することは難しく, 危険側の判断に なりやすいことを意味する.

前述したように，型枠に投入したコンクリートが完全 に締固めができたとすれば，その高さは36.5cmになるべ きである.しかし，図-12の写真(3)からわかるように， 試験体の上面には，36.5cm以上に盛り上がった部分があ る. したがって，盛り上がった部分以下のコンクリート は理論密度に達しているとはいえないため, 締固め完了 とは言えない，高さが36.5cmになった範囲を測定すると， 振動機からの距離は21.0cmである。この位置はかぶり部 をカットして確認した締固め範囲12.8〜25.6cmの間であ ることとほぼ合致しており, また, 前章で求めた締固め 完了範囲は表-4に示寸通り 22.2cmであるため, 計算値と もほぼ一致する．表-4に示すように，スランプ12，15cm
の場合も計算値と最小締固め範囲を示す上面盛り上がり 状態の測定值はほぼ一致している。これは, 締固めエネ ルギーによる締固め範囲の評価が可能であることを意味 する.

以上の測定結果より算出した各配合のコンクリートが 十分締め固められるのに必要な内部振動機の挿入間隔と 締固め時間の関係を図-13に示す，図により，施工計画 段階で，施工に使用するコンクリートの配合によって内 部振動機の挿入間隔と振動時間を決めるか，あるいは決 められた挿入間隔と振動時間によって, コンクリートの 十分な締固めを保障することができるコンクリートの配 合を選定することができる，例えば，図-13において， スランプ12cmの配合の場合は, 締固め時間15秒間で挿 入間隔46cmであれば，コンクリートは理論密度まで締 め固まると判断することができる.

スラブの施工を一例とした場合, 内部振動機の締固め 範囲は円形である. 図-14に示すように，締固めが不十 分の領域を残さないためには締固め範囲が重なるように する必要があるので内部振動機の挿入間隔は締固め範囲 の2倍ではなく，それより小さくなることに留意する必 要がある．たとえば，図-14に示すように，内部振動機 の挿入間隔が46cmである場合，コンクリートが完全に 締め固められるために必要な内部振動機の締固め完了範 囲は23cmではなくて最大で32.5cmになる.したがって, 施工計画の段階で，内部振動機の挿入間隔を決める時に は, 内部振動機の締固め影響範囲と締固め時間とともに, 挿入位置も考慮すべきである.

\section{5. 過振動を受けたコンクリートの品質への影響の 確認試験}

内部振動機はコンクリートの中で振動することによっ て，コンクリートに締固めエネルギーを与え，コンクリ 一トを締め固める．図-13に示すように，挿入間隔が大 きくなると，振動機から遠くなるにしたがいエネルギー は減衰するが，内部振動機の振動時間を長くすることに より，充分な締固めを行うことができる. しかし，充分 に締固めを行うための振動時間は，示方書施工編に示さ れた標準的な締固め時間である15秒を超えざるを得ない． 内部振動機の最大挿入間隔を $55 \mathrm{~cm}$ とした場合, 図-13の 曲線が示寸スランプ8，12，15cmのコンクリートの締固 め時間の範囲はそれぞれ0６0秒，0〜30秒，0１5秒で ある. 図-13に示す曲線を施工に適用するためには，示 された締固め時間の範囲内でのコンクリートの品質を確 認する必要がある.

本研究では，スランプ8cmのコンクリートを締固め時 間を60秒として，スランプ15cmのコンクリートは締固 め時間を30秒にして, 過振動を受けた試験体を作製し, 

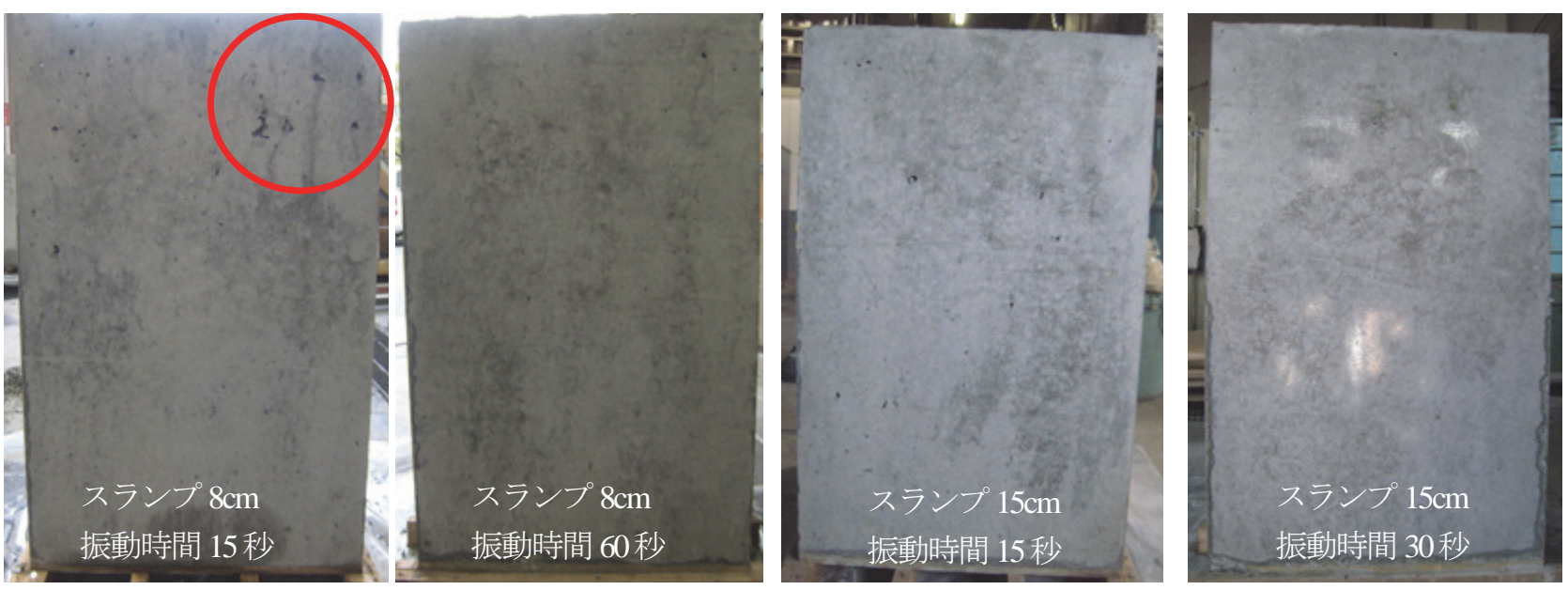

図-16 試験体の側面の表面状況
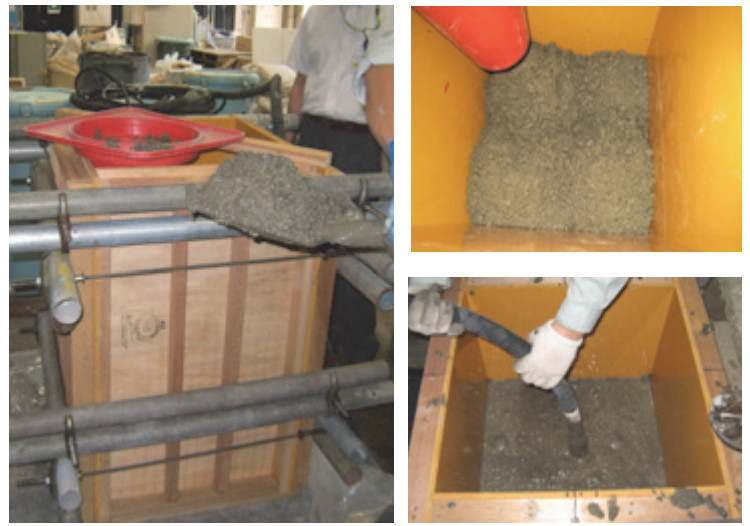

図-15 分離抵抗性試験体打設状況

コンクリートが過振動を受けた場合の品質を確認した. スランプ $8 \mathrm{~cm}, 15 \mathrm{~cm}$ のコクリートの標準試験ケースと して，内部振動機の振動時間を15秒にした試験体もそれ ぞれ製作した．図-15に示寸断面寸法500×500mmで高さ 800mmの木製型枠を用いて試験体を作製した。一層の打 設高さを400mmで二層打ちにし， $\phi 50 \mathrm{~mm}$ の内部振動機 を型枠の中心に挿し込み，コンクリートの締固めを行っ た.内部振動機は下の層に100mm挿入して締め固めるよ うにした．実際の施工を模擬するため，打重ね時間間隔 を30分とし，打設口を直径100mmとしたロードコーンを 介して一層当り4箇所に分けて型枠内にコンクリートを 連続投入した。

打込久終了後，材齢5日まで湿潤養生して脱型し，28 日まで恒温恒湿室 $\left(20^{\circ} \mathrm{C} ， 60 \%\right)$ にて養生した．試験体の 表面状況を図-16の写真に示す．振動時間を60秒にした 試験体(スランプ8cm)の表面の仕上がりは良好である. 過振動による材料分離で発生するとされている縞模様の 砂すじは見られてない，逆に振動時間を15秒にした標準 試験体(スランプ8cm)には，大きな空気泡が見られてい
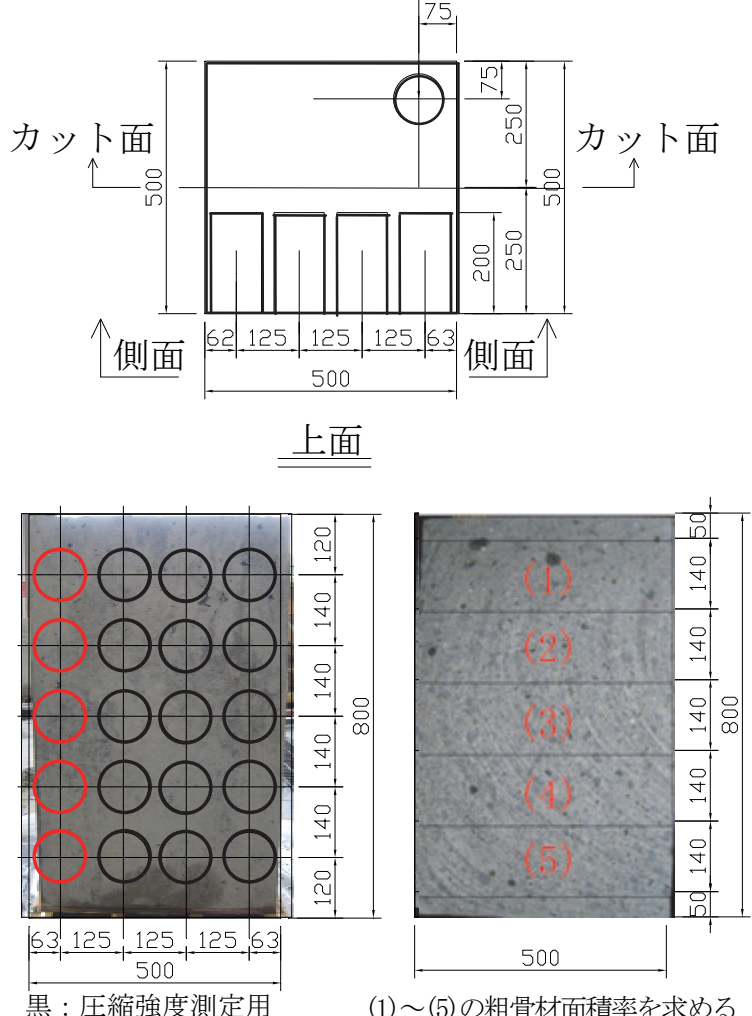

赤 : 促進中性化試験用 側面

（1）（5)の粗骨材面積率を求める

カット面

図-17 トレント法による透気係数の測定位置, コアの採取位置および粗骨材率測定位置

る．スランプ15cmの場合でも，過振動を受けた試験体 の表面状況は標準試験体に比較して大きな差異はない.

材齢28日で，試験体側面から $\phi 100 \mathrm{~mm}$ のコアを採取し， 圧縮強度試験(3本平均)および，JIS A 1153に準じた促進 中性化試験を行った。コアの採取位置を図-17に示す. コアの採取前に，図-17の側面の図中の赤 $\bigcirc$ 部で，材齢 
28日でトレント法により透気係数を計測した. その後, 試験体を断面中央部でカットして，縦断面の上下 $50 \mathrm{~mm}$ の部分を除いた部分を140mm間隔で5部分に分け，粗骨 材面積分布率を測定した。また，試験体の頂面から鉛直 に長さ $800 \mathrm{~mm}$ のコアを採集し，8部分に均等に分断し， 絶乾密度を測定した．以上のデータを用いて，過振動を 受けた試験体と標準試験体の品質を比較検討した.

トレント法により透気係数を計測した結果を図-18に 示す，図に示すように，過振動を受けた試験体の測定結 果は標準試験体と比較して大きな差が見られない. 逆に, スランプ8cmの場合には，加振時間が長い試験体の方が 若干良い結果を示している.

コアの絶乾密度と圧縮強度の試験体下面からの距離に 応じた分布を図-19に示す，図に示すように，過振動を 受けた試験体の圧縮強度および絶乾密度は標準試験体と 比較して大きな差がないことがわかる．打重ね部である 300～400mm高さの圧縮強度には変動がみられるが，圧 縮強度の変化は平均值の $\pm 10 \%$ 以内に収まっている。ま た，試験体上面の圧縮強度が若干小さくなっているが, 次の層を打ち込んで締め固めることで打重ね部と同じよ うになると考えられる。

粗骨材面積分布率と促進材龃26週における中性化深さ の試験体下面からの距離に応じた分布を図-20に示す. 四に示すように，バラツキはあるが，過振動を受けた試 験体のカット面の粗骨材面積率は標準試験体の粗骨材面 積率とは大きな差が無い. 断面の状況からも粗骨材の分 布の偏りは見当たらなかったことから，コンクリートの 粗骨材の材料分離はなかったと考えられる. 打重ね部で ある300〜 400mm高さの部分の粗骨材面積率がほかの部 分に比べて小さくなっているが，加振時間による差は見 られてない。促進中性化試験の結果にも差はほとんど 見られない.

一般的に，コンクリートが過振動を受けると，コンク リートが分離すると言われているが，本実験のように型

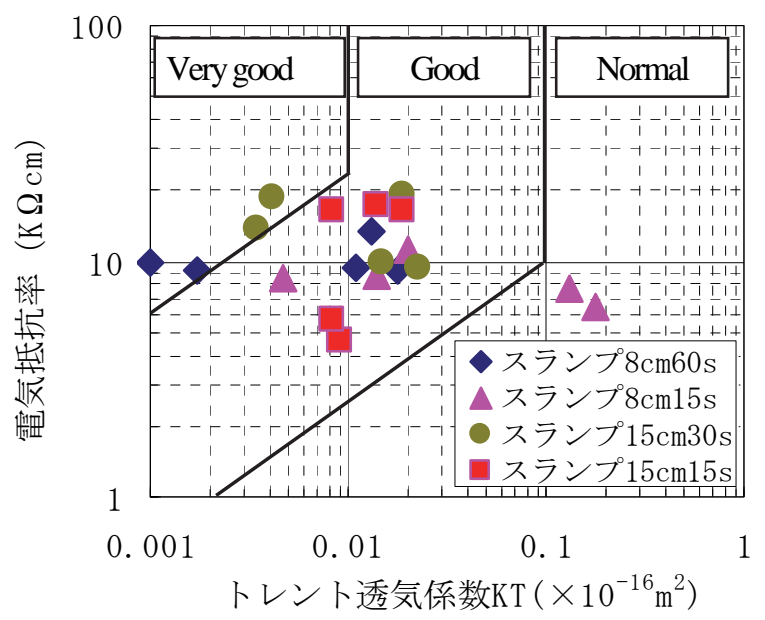

図-18 透気係数測定の結果
枠の平面的な拘束がある条件下で過振動を受けたコンク リート試験体の品質は標準試験体に比べて大きな差が見 られなかったことを以上の実験結果が示している. コン クリートは内部振動機の振動により液状化されることで 締め固められる. 型枠などの拘束がない状態でコンクリ 一トが液状化されると, モルタルの流出により，コンク リートは分離する. しかし, 型枠の拘束がある状態でコ

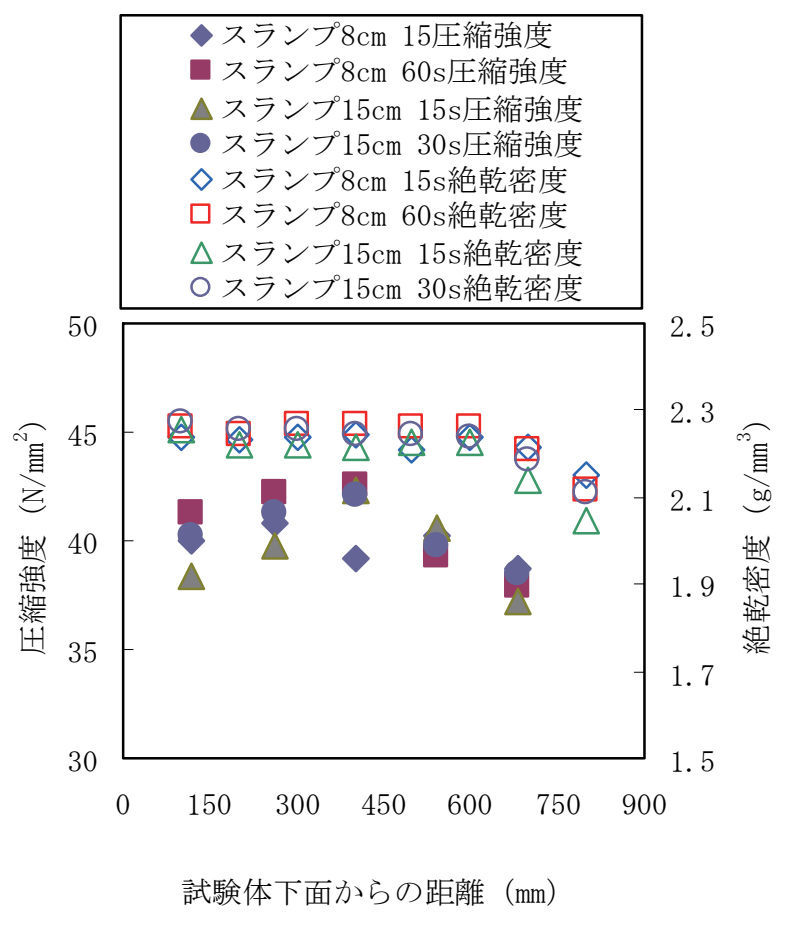

図-19 コアの絶乾密度と圧縮強度

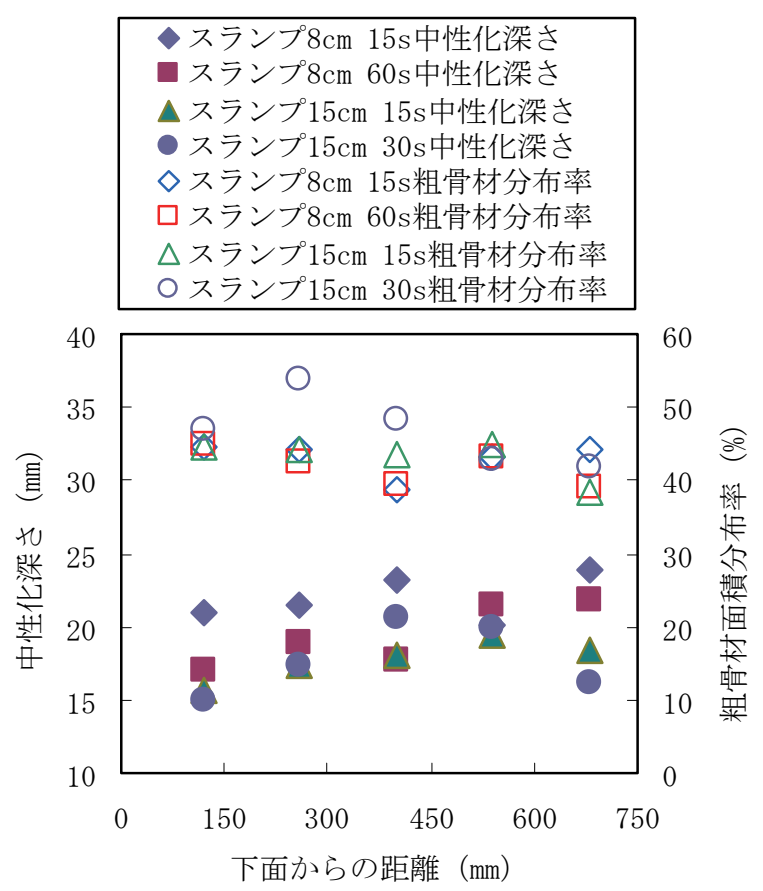

図-20＼cjkstart粗骨材面積分布率と中性化深さ 
ンクリートが液状化されると，モルタルの流出がないた め，間隙水圧の保持により，骨材は重力の影響を受けず， ペースト中に均一に分布される。 したがって，筒先付近 で締固めを行う先行締固めにおいては，材料分離を防ぐ ため，標準的な締固め時間を守らなければならないが， 仕上げの締固めを行う後追い締固めにおいては, コンク リートのモルタル分が流される恐れがないため，適当に 締固め時間を長くしても品質上は問題がないと考えられ る.なお，締固め時間を長くすることで，レイタンス量 が多くなるため，打重ね面となる場合は，レイタンス処 理を十分に行う必要がある．以上より，図-13に示す 15 秒を超える時間の締固めを前提とした評価結果を次章に 記す施工試験に適用しても差しつかえないと考えられる.

\section{6. 実大規模施工実験による検証}

以上の検討結果の妥当性を確認するため, 模擬試験体 で対象とした部材の実大規模の施工実験を行った。コン クリートの配合は表-1の配合，材料は表-2の材料を使用 した．本実験では，図-21に示すように，ストラットと 上床版が組み合わさった部分を模擬した $2.0 \mathrm{~m} \times 3.0 \mathrm{~m} \times$ $7.5 \mathrm{~m} の$ 実寸大試験体をポンプ筒先でのスランプが $12 \mathrm{~cm} の$ コンクリートで作製した．また，図-21で配筋が最も過 密である赤枠で囲まれた部分を模擬して $2.5 \mathrm{~m} \times 2.5 \mathrm{~m} \times$ $2.0 \mathrm{~m}$ の小型供試体をポンプ筒先でのスランプが $8 \mathrm{~cm} の コ$ ンクリートで作製した．締固め条件はスランプの大小に 関わらず，コンクリート内部まで挿入後の締固め時間を 15秒，挿入間隔を $46 \mathrm{~cm}$ とて行った。 コンクリートの

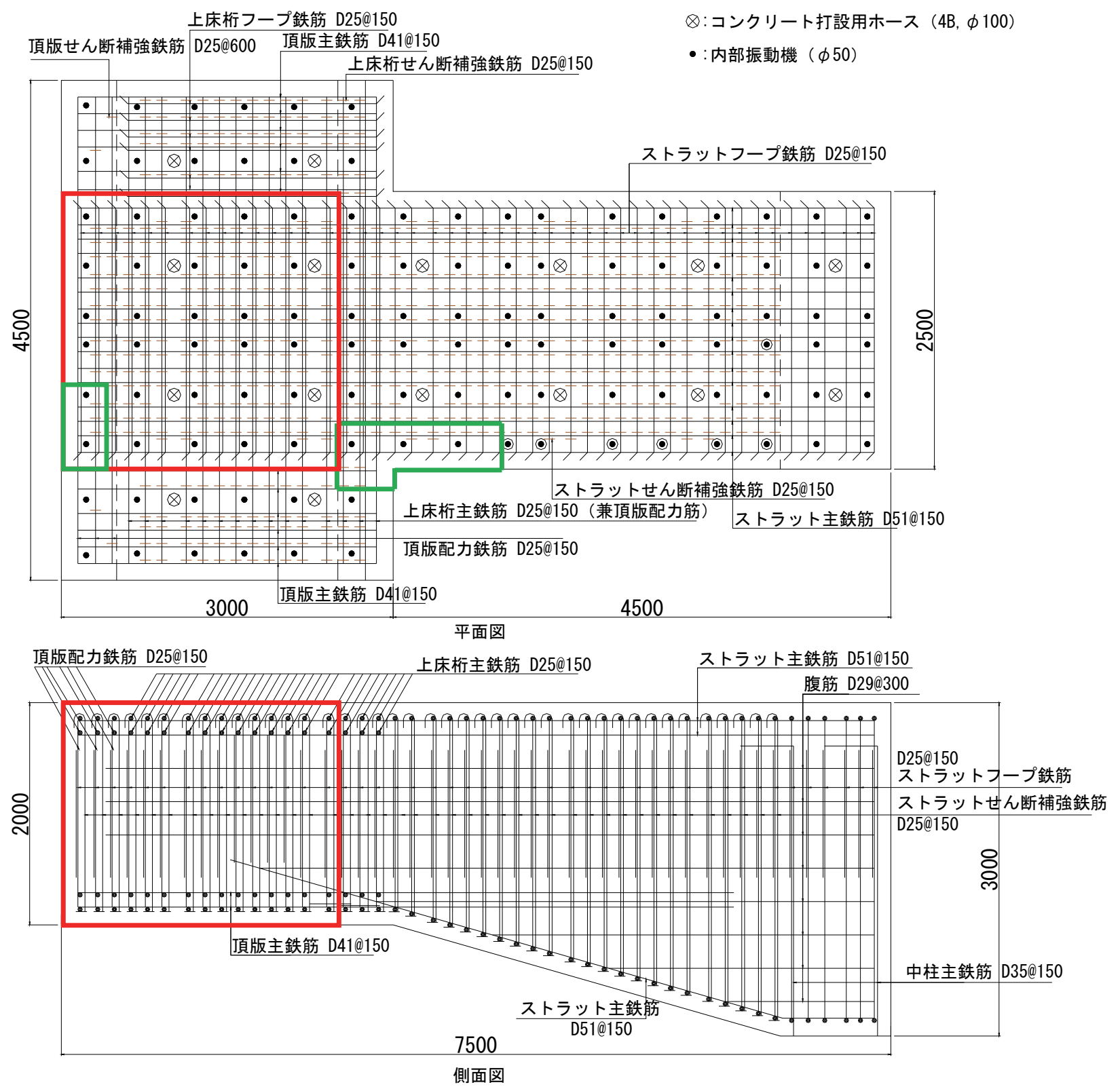

図-21 実大実験供試体の配筋状況および寸法 


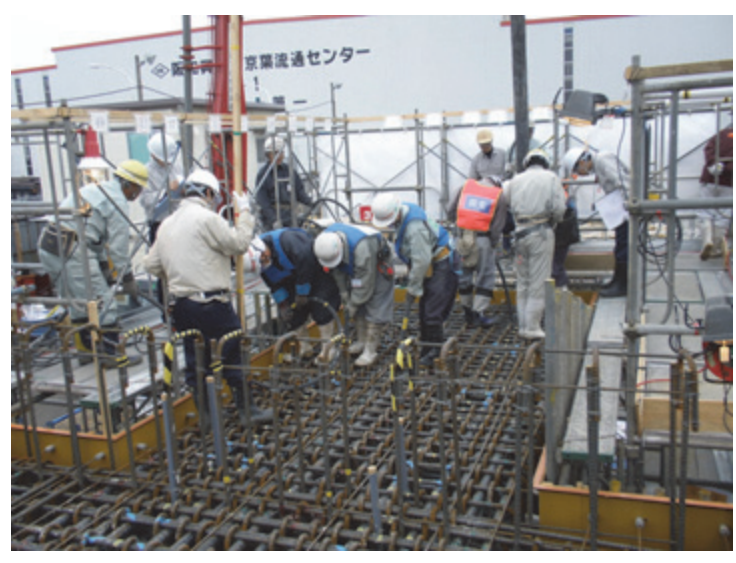

図-22 圾験体の施工状況の全景

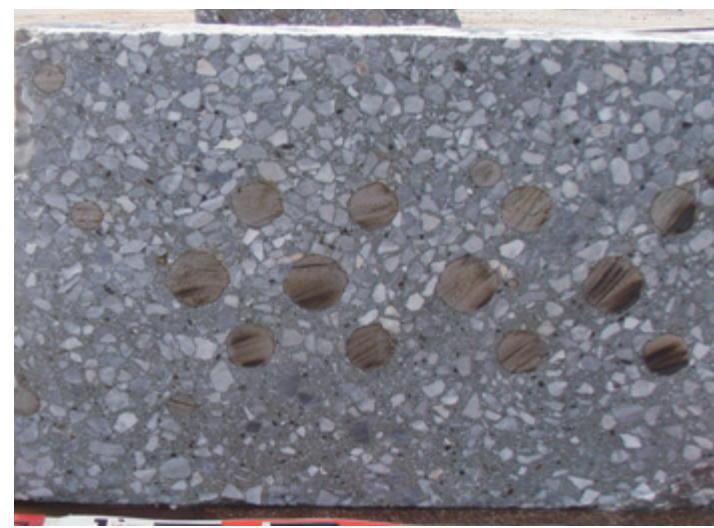

図-23 試験体の切断面の状況(スランプ 12cm)

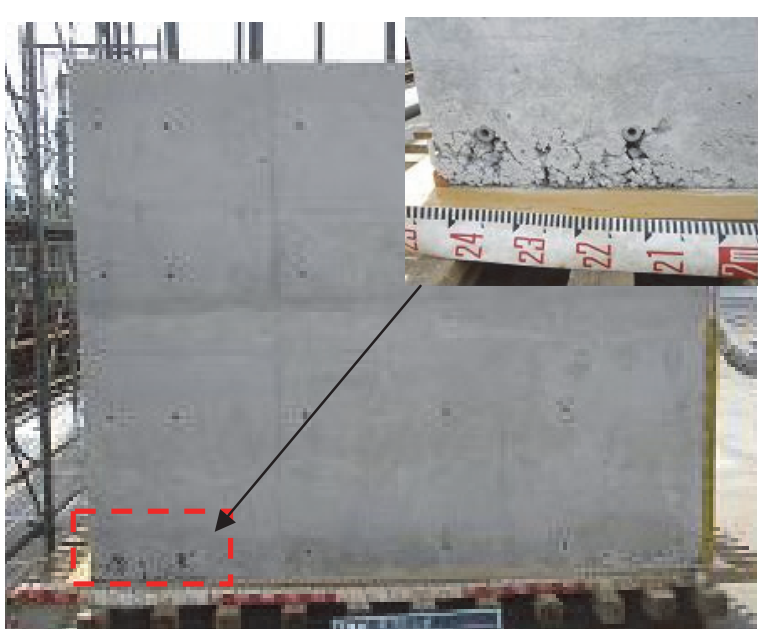

図-24試験体の切断面の状況(スランプ 8cm)

締固めは，図-13に示すように，スランプ12cmのコンク リートは締固め時間15秒，扦入間隔を46cmで理論密度 まで締め固められるが，同じ締固め条件でスランプ8cm のコンクリートは締固めが不充分な箇所が生じるため, 不具合が発生する可能性がある．図-22に試験体の施工 状況の全景を示す.

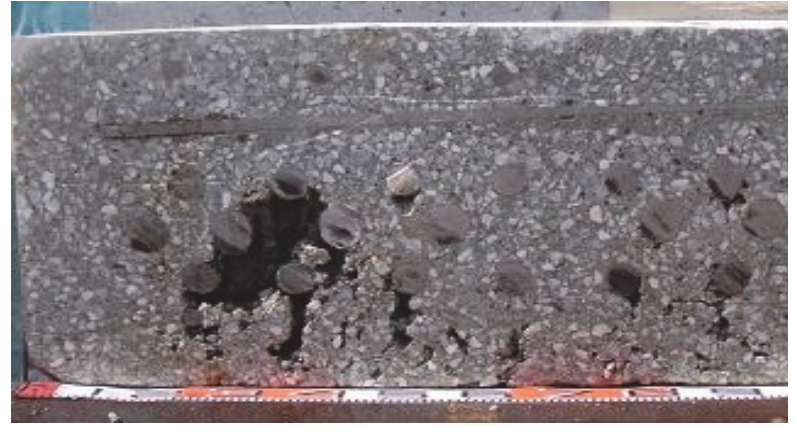

図-25試験体の切断面の状況(スランプ 8cm)

本研究では，両実寸試験体から底面付近が過密配筋部 である図-21の緑線に囲まれた部位を切り出し，コンク リートの充填状況を確認した．スランプ12cmのコンク リートを打設した試験体は，表面状況が良好で切断面も 図-23が示すように，コンクリートが密実に締め固めら れている.

一方，スランプ8cmを打設した試験体の表面は図-24が 示寸ように底面の過密配筋部の表面に充填不良部が生じ ている.

不具合が生じた部位の切断面の写真を図-25に示す. 同写真からわかるように，スランプ8cmの配合のコンク リートを打設した試験体は，切断面で鉄筋の下にコンク リート充填が不十分な部分が存在しており，このような 部分の範囲は試験体外観から判断した範囲より大きかっ た.

図-13に示寸ように，スランプ12cmの配合の場合，内 部振動機の振動時間が15秒で挿入間隔が46cm以下であ れば十分締固めができる．スランプ8cmの場合，内部振 動機の振動時間が15秒で締固めが確保できる挿入間隔は 33cm程度である. 前述通り, 試験時の締固め時間およ び挿入間隔はそれぞれ15秒，46cmで一定としたため, スランプ12cmの配合の試験体は十分に締め固められる が，スランプ8cmの配合の試験体は充填不良が発生する ことが予想され，前述のように本試験では予想通りの結 果となった. このことより，締固め完了エネルギーによ る締固め完了範囲の評価方法が実施工にも適用できるこ とが実証された。

本試験結果から最適スランプとしてスランプ $12 \mathrm{~cm}$ 選定したが，最終的に選定するコンクリートのスランプ は材料のばらつき, 表面水率のばらつき, 空気量のばら つきなどからによるコンクリートの品質にはばらつきを 考慮しなければならない.

\section{7. まとめ}

実構造物の配筋をモデル化した模擬試験体を用いて, コンクリートのスランプをパラメータとし，コンクリー 
トが締固め完了するのに必要なエネルギーを定量的に評 価し，実大規模の施工試験により検証した結果，以下の ことが明らかとなった。

(1)施工に必要となる内部振動機の挿入間隔と振動時 間を定量的に評価することは可能である.

(2)締固めエネルギーにより締固め完了と評価した範 囲の計算結果と実構造物をモデル化した模擬試験体にお ける締固め完了範囲はほぼ一致する。また，実寸大試験 体試験結果も締固め完了エネルギーによる評価と一致し ている．累積された内部振動機による振動エネルギーが, コンクリートの締固めを完了するのに必要なエネルギー 以上となった範囲を締固め完了範囲とすることで, 鉄筋 コンクリートの締固め完了範囲を評価することが可能で ある。

(3)不具合が発生した試験体内部の充填不十分の程度 を確認した結果，表面から目視で判断した充填不良の範 囲より大きいことから，コンクリート表面の充填状態を 表面状態の見た目で判断するだけでは締固めの程度を判 断することは難しく，危険側の判断になる可能性がある. これに対して，締固め完了エネルギーによる評価結果は， 試験体内部の充填不良部の範囲とほぼ一致した.

\section{参考文献}

1) 土木学会 : 2007 年制定コンクリート標準示方書[施工 編], pp. 121-122, 2008.3.

2) 日本道路協会 : 道路橋示方書 - 同解説 IV 下部構造編, pp.110-119, 1996.

3) 国島正彦：コンクリート構造物の耐久性に及ぼす設 計過程の影響, 土木学会論文集, No. 421/VI-13, pp. 165-174, 1987.11.

4) 村田二郎：フレッシュコンクリートの挙動に関する 研究, 土木学会論文集, No. 378/V-6, pp. 21-33, 1987.11.

5) 岩崎訓明 : 振動によるフレッシュコンクリートの液 状化と内部振動機の作用領域に関する考察, 土木学
会論文集，No. 426/V-14, pp. 1-18, 1991.11.

6) Banfill, P. F. G., Teixeira, M. A. O. M and Craik, R. J. M.: Rheology and vibration of fresh concrete: Predicting the radius of action of poker vibrators from wave propagation, Cement and Concrete Research, Vol. 41, pp. 932-941, 2011.

7) 梁俊, 丸屋剛, 坂本淳, 宇治公隆 : 締固め完了エネ ルギーによる同一スランプコンクリートの施工性評 価, コンクリート工学年次論文集, Vol. 31, No. 1, pp. 1393-1397, 2009.7.

8) 日本コンクリート工学協会 : 施工の確実性を判定す るためのコンクリートの試験方法とその適用性に関 する研究報告書, pp. 67-72, 2009.7.

9) 土木学会 : コンクリートライブラリー 26 , 施工性能 にもとづくコンクリートの配合設計・施工指針, 2008.5 .

10) 土木学会：コンクリート技術シリーズ 94, コンンク リートの施工性能の照査・検査システム研究小委員 会（341委員会）委員会報告書, 2011.5.

11) 梁俊, 國府勝郎, 宇治公隆, 上野敦 : フレッシュコ ンクリートの締固め性試験法に関する研究, 土木学 会論文集，Vol. 62, No. 2, pp. 416-427, 2006.6.

12) 國府勝郎, 上野敦 : 締固め仕事量の評価に基づく超 硬練りコンクリートの配合設計, 土木学会論文集, No. 532/V-30, pp. 109-118, 1996.2.

13) 國府勝郎, 他：コンクリート施工設計学序説, 技報 堂出版, pp. 142-143, 2004.

14) 梁俊, 宇治公隆, 國府勝郎, 上野敦 : スランプの相 違がフレッシュコンクリートの締固め性に与える影 響, セメント・コンクリート論文集, No. 59, pp. 146151, 2005.2.

15) 梁俊, 丸屋剛, 坂本淳：フレッシュコンクリート中 における振動加速度の測定方法に関する研究, 土木 学会第 66 回年次学術講演会講演概要集, V-117, pp. 233-234, 2011.9.

16) 梁俊 : 締固めエネルギーに基づくフレッシュコンク リートの締固め性評価手法，博士論文，pp. 81-85, 2006.3.

(2013. 2. 5 受付)

\title{
METHOD FOR COMPACTABILITY EVALUATION OF CONCRETE BASED ON COMPACTION COMPLETION ENERGY
}

\author{
Jun LIANG, Tsuyoshi MARUYA, Jun SAKAMOTO, Junichi MATSUMOTO, \\ Taizo SHIMOMURA and Masanori TAKIZAWA
}

In this research, the authors used element test samples which modeled actual structures, to consider a quantitative method for evaluating the internal vibrator insertion intervals and compaction times necessary for concrete used in construction, based on the concrete compaction completion energy, using concrete slump as a parameter. The following conclusions were reached. The theoretical compaction completion ranges calculated from compaction energy were almost identical to the actual compaction completion ranges of elemental tests modeled on actual structures. It is difficult to evaluate the degree of compaction purely through visual evaluation of the cast condition of the form surface, and doing so is risky. In follow-up compaction, even if compaction time gets longer properly, quality does not have any problem. 